DOI: 10.22630/EIOGZ.2014.106.14

Zeszyty Naukowe Szkoły Głównej Gospodarstwa Wiejskiego

Ekonomika i Organizacja Gospodarki Żywnościowej nr 106, 2014: 45-56

Jacek Uchman

Katedra Finansów

Uniwersytet Ekonomiczny we Wrocławiu

\title{
Opodatkowanie dochodów a inwestycje w przedsiębiorstwie
}

\section{Wstęp}

System podatkowy może wpływać na przedsiębiorstwa wielotorowo, także poprzez zróżnicowanie podatków. Skala skutków jego oddziaływania jest trudna do kwantyfikacji. Wpływ podatków można analizować empirycznie na konkretnych przypadkach. Teoria finansów przedsiębiorstw koncentruje się przede wszystkim na czynnikach zależnych od samych firm i nie wypracowała rozbudowanych narzędzi analizy oddziaływania systemu podatkowego na przedsiębiorstwo ani jednoznacznych wskazówek dotyczących ich optymalnego opodatkowania. Jednak jasne jest, że podatki jako czynnik zewnętrzny w stosunku do przedsiębiorstwa mogą kształtować zachowania i sytuację finansową przedsiębiorstw. Podatki mogą wpływać przede wszystkim na zysk przedsiębiorstwa będąc jednym z elementów jego podziału. W tej roli występują podatki dochodowe. Podatki obrotowe i do pewnego stopnia podatki dochodowe mogą natomiast kształtować płynność finansową firmy. Dotyczy to zarówno przedsiębiorstw małych, jak i dużych.

System podatkowy może więc oddziaływać na przedsiębiorstwo wielokierunkowo. W największym stopniu decyzje przedsiębiorstw kształtują podatki dochodowe i podatek od towarów i usług. Należy pamiętać, że podatki dochodowy i VAT są czynnikami zewnętrznymi w stosunku do przedsiębiorstwa, dlatego pytanie o ich kształt jest również częściowo pytaniem o priorytety polityki fiskalnej państwa w tym obszarze.

Celem artykułu jest analiza teoretyczna wybranych mechanizmów w obszarze podatków dochodowych przy wykorzystaniu zasady neutralności w kontekście istniejących regulacji w polskich podatkach dochodowych. 


\section{Inwestycyjne preferencje podatkowe a zasady podatkowe}

W przypadku podatków dochodowych duże znaczenie mają różne instrumenty wkomponowane $\mathrm{w}$ ich funkcjonowanie ${ }^{1}$. W ocenie specjalnych preferencji podatkowych pomocne mogą być sformułowane dawno temu zasady podatkowe. Stwarzają one podstawę do rozważań, jakie rozwiązania stosować w systemie podatkowym w badanym obszarze bez naruszania reguł racjonalności. Dotyczą nie tylko całego systemu podatkowego, ale także szczegółowych rozwiązań w obszarze materialnego prawa podatkowego. Oczywiście nie maja one statusu norm prawnych. Ich realizacja nie jest wymagana przez prawo, ale mają one charakter postulatów praktycznych.

System podatkowy może być uznawany za racjonalny, jeżeli spełnia elementarne zasady podatkowe lub jest skonstruowany na ich podstawie. Do zasad podatkowych sformułowanych jeszcze przez A. Smitha należą: zasada równości, zasada taniości, zasada dogodności i zasada pewności podatku. Nie wszystkie $\mathrm{z}$ tych zasad są spełnione przez polski system podatkowy. Najbardziej dyskutowaną zasadą jest niewątpliwie zasada równości podatkowej ${ }^{2}$.

Obok sformułowanych przez A. Smitha zasad podatkowych szczególnego znaczenia w latach 70. i 80. ubiegłego wieku nabrała zasada neutralności opodatkowania. Jest ona bardzo przydatna do oceny podatkowych zachęt inwestycyjnych. Zasada neutralności stanowi, że podatek nie powinien modyfikować wyborów rynkowych podmiotów gospodarczych. Zasada ta wynika z faktu, że podmioty na rynku podejmują decyzje na podstawie porównania przychodów i kosztów (czyli rachunku ekonomicznego). Jeśli podatek wpływa na jedną z tych

\footnotetext{
${ }^{1}$ Rozważane są tylko podstawowe mechanizmy proinwestycyjne funkcjonujące w ramach podatku dochodowego od osób fizycznych (PIT) i podatku dochodowego od osób prawnych (CIT). Rozważania dotyczą tylko inwestycji rzeczowych przedsiębiorstw.

${ }^{2}$ Równość podatkowa jest odnoszona zazwyczaj do podatku dochodowego od osób fizycznych. Może być ona rozpatrywana w dwojaki sposób. Wyróżnia się tak zwaną równość poziomą i równość pionową. Równość pozioma (horyzontalna) oznacza, że podatnicy o równym poziomie dochodów lub takim samym poziomie konsumpcji powinni być identycznie opodatkowani przez odpowiednie podatki. Równość pionowa polega na tym, że podatnicy o nierównych dochodach powinni być nierówno opodatkowani. Oznacza to, że podatnicy o mniejszym dochodzie powinni być niżej opodatkowani niż podatnicy o wyższym dochodzie. Poziom nierówności opodatkowania jest kwestią dyskusyjną. W zakresie podatku dochodowego może być zastosowany zarówno podatek progresywny, jak i podatek o stawkach liniowych. Pozostałe zasady podatkowe dotyczą sprawności systemu podatkowego i mogą stanowić kryterium oceny specjalnych preferencji inwestycyjnych.
} 
pozycji, może wtedy zakłócać wybory rynkowe ${ }^{3}$. Postulat neutralności oznacza więc, że podatek nie może w nadmierny sposób ingerować w mechanizm rynkowy. Zasada ta może być do pewnego stopnia sprzeczna $\mathrm{z}$ zasadą równości. Należy przy tym dodać, że w pewnych szczególnych przypadkach zwolennicy zasady neutralności akceptują jej łamanie, jeśli jest to uzasadnione społecznie (np. wysokie opodatkowanie alkoholu akcyza).

Za neutralny powszechnie uznaje się podatek, który nie zakłóca wyborów dokonywanych przez rynek, a neutralne podatkowo zachęty inwestycyjne to takie, które nie zakłócają wyborów dokonywanych z wykorzystaniem rynkowych kryteriów opłacalności.

Neutralność może być więc rozpatrywana w sposób szeroki, tzn. może być odnoszona do całego systemu podatkowego bądź do konkretnego podatku i rozpatrywać jego podstawowe elementy. Neutralność może również być odnoszona do konkretnych rozwiązań w ramach systemu podatkowego, w tym zachęt inwestycyjnych.

Także neutralność zachęt inwestycyjnych może być analizowana w różny sposób. Najbardziej oczywistym przejawem neutralności w tym obszarze jest sytuacja, w której jednakowe korzyści mogą osiągnąć różne podmioty bez względu na ich formę organizacyjno-prawną oraz miejsce prowadzenia działalności. Ten aspekt nie jest ujmowany $\mathrm{w}$ definicjach, ale jest zakładany domyślnie.

Koncepcja neutralności podkreśla pewne istotne niebezpieczeństwo związane ze stosowaniem preferencji inwestycyjnych. Podatkowe zachęty inwestycyjne oznaczaja, że stymuluje się rozwój takich inwestycji, które bez funkcjonowania ulgi nigdy nie zostałyby podjęte. Jednocześnie ważne jest, żeby instrumenty te nie powodowały sytuacji, w których byłyby realizowane inwestycje mniej rentowne od tych, które mogłyby być realizowane gdyby preferencyjnych regulacji nie było.

Powyższe zjawisko może mieć miejsce wtedy, gdy rodzaj inwestycji, którym przysługuje preferencja, jest określony bardzo wąsko. Może wtedy występować specyficzny mechanizm wypychania przedsięwzięć, którym nie przysługują preferencje podatkowe, a których realizacja byłaby właściwa ze względu na kryteria rynkowe. Jednak nawet $\mathrm{w}$ sytuacji, gdy zakres inwestycji obejmowany przez ulgę jest dosyć szeroki, mogą następować naruszenia tego postulatu.

Definicje neutralności obniżek i ulg dotyczą zazwyczaj tej drugiej sytuacji (szeroki zakres). Najprostsza, ale precyzyjna definicja neutralności została sfor-

\footnotetext{
${ }^{3}$ W ten sposób np. podatek dochodowy o stawkach progresywnych może spowodować ograniczenie korzyści z pracy nie redukując jednocześnie wymiaru tej pracy i jej intensywności.
} 
mułowana przez A.C. Harbergera ${ }^{4}$. Mówi ona, że neutralny bodziec podatkowy to taki, który nie zachęca do dokonywania inwestycji o niskiej społecznej, wewnętrznej stopie zwrotu (tzn. IRR bez uwzględnienia ulg podatkowych oraz amortyzacji degresywnej) poprzez wypychanie innych objętych ulgą inwestycji o wysokiej, społecznej wewnętrznej stopie zwrotu [Harberger 1980, s. 299 i nast.].

Jeżeli więc preferencje podatkowe spowoduja, że w grupie preferowanych inwestycji wybrany zostanie wariant o znacznie niższej społecznej wewnętrznej stopie zwrotu, ale bardziej opłacalny po uwzględnieniu preferencji podatkowych, wtedy następuje zakłócenie normalnych, rynkowych procesów decyzyjnych.

\section{Determinanty inwestycji w przedsiębiorstwie}

Poziom inwestycji w firmie jest determinowany różnymi czynnikami. Często wymienia się jako dominującą oczekiwaną stopę zwrotu z kapitału. Wzrost inwestycji może być ujmowany jako funkcja przyszłych zmian w wielkości sprzedaży, bądź też jako stosunek zdolności produkcyjnych do wielkości sprzedaży. Wielkość ich może być także wyznaczona przez dostępność do tanich źródeł finansowania w firmie. Szczególnie ten ostatni czynnik w warunkach gospodarki polskiej wydaje się być bardzo ważny. W praktyce obniżenie poziomu inwestycji w gospodarce często występuje wtedy, gdy dochodzi do recesja i obniżenie poziomu zysków.

Trudności w zastosowaniu polityki antycyklicznej i częściowa falsyfikacja różnych modeli teoretycznych makroekonomii spowodowały, że nie można obecnie wskazać jednoznacznie, jakie mechanizmy w ramach systemu podatkowego byłyby właściwe dla wzrostu poziomu inwestycji w przedsiębiorstwach.

Ponieważ ocena oddziaływania podatków dochodowych (a tym bardziej sytemu podatkowego) na poziom i opłacalność inwestycji przedsiębiorstw w skali makroekonomicznej jest bardzo złożona, dlatego dla potrzeb niniejszych rozważań wygodniej będzie przyjąć podejście redukcyjne. Najprościej można to przedstawić idąc tropem popularnych finansowych modeli oceny opłacalności inwestycji rzeczowych. I tak przy ocenie opłacalności dokonywanej za pomoca modelu NPV podstawowymi czynnikami są wysokość przepływów pieniężnych generowanych przez inwestycję i poziom stopy dyskonta. Przepływy i stopa dyskonta są kształtowane przez podatek dochodowy.

\footnotetext{
${ }^{4}$ Analiza Harbergera wydaje się być najlepszą jak dotąd analizą inwestycyjnych ulg podatkowych o charakterze inwestycyjnego kredytu podatkowego z punktu widzenia zasady neutralności opodatkowania. Po reformie podatkowej z 1986 roku w USA, w której znacznie obniżono stawki podatków dochodowych a jednocześnie wyeliminowano ulgi inwestycyjne, problem ten z natury rzeczy stracił na znaczeniu w rozważaniach teoretycznych w USA.
} 
Tabela 1

Inwestycje w Polsce w latach 2005-2010

\begin{tabular}{|l|c|c|c|c|c|c|c|}
\hline Lata & 2005 & 2006 & 2007 & 2008 & 2009 & 2010 & 2011 \\
\hline $\begin{array}{l}\text { Nakłady inwestycyjne } \\
\text { (rok poprzedni = 100) }\end{array}$ & 107,7 & 116,8 & 120,4 & 110,7 & 99,2 & 100,2 & 110,6 \\
\hline
\end{tabular}

Źródło: Rocznik Statystyczny GUS 2012.

Problem podatkowych preferencji inwestycyjnych dla podmiotów gospodarczych w systemie podatkowym zazwyczaj traci na znaczeniu w sytuacji wysokiego poziomu inwestycji podmiotów gospodarczych. Kiedy jednak poziom inwestycji się obniża, władze są motywowane (gospodarczo i politycznie) do podejmowania decyzji zmierzających do podniesienia tego poziomu w ramach instrumentów polityki monetarnej (obniżka stóp procentowych) i fiskalnej. Powracają wtedy także pomysły dotyczące rozszerzania preferencji podatkowych.

Przy różnych ograniczeniach w korzystaniu z zewnętrznych źródeł finansowania wydaje się, że zysk i amortyzacja mają duże znaczenie dla finansowania inwestycji i ich poziomu w przedsiębiorstwie. Poziom inwestycji w firmie zależy więc także od czynników kształtujących poziom zysku. Jednym z najistotniejszych elementów wpływających na wielkość wyniku finansowego jest podatek dochodowy.

\section{Regulacje w zakresie opodatkowania dochodów kształtujące możliwości inwestycyjne przedsiębiorstw}

Podatek dochodowy może kształtować wielkość wyniku finansowego w różny sposób. Przede wszystkim poprzez wysokość stawek podatkowych decydujących o wielkości pozostawionego $\mathrm{w}$ firmie zysku ${ }^{5}$. Podatek dochodowy może wpływać na wielkość wyniku finansowego poprzez ulgi podatkowe związane $\mathrm{z}$ realizowaniem inwestycji (obecnie w zasadzie nie występują). Innym ważnym instrumentem jest stosowanie degresywnej amortyzacji wpływającej bezpośrednio na wielkość dodatkowych funduszy pieniężnych, a także na wymiar zobowiązań z tytułu podatku dochodowego. Stosowanie amortyzacji degresywnej oznacza, że suma zobowiązań podatkowych jest taka sama jak w sytuacji, gdy stosuje się amortyzację liniowa, inny natomiast jest ich rozkład w czasie. Najwyższe zobowiązania podatkowe występują w końcowym okresie eksploatacji

${ }^{5}$ Duże znaczenie dla ciężaru podatkowego ma także rodzaj rynku i charakter konkurencji. W przypadku rynków zmonopolizowanych ciężar podatku można częściowo przerzucać na odbiorców czy pracowników. 
środka trwałego. Powoduje to odmienne konsekwencje w zakresie zakłócania neutralności podatku. Bardziej opłacalne z podatkowego punktu widzenia jest nabywanie środków trwałych o długim okresie eksploatacji. Wynika to z faktu, że nieoprocentowany kredyt, którym jest taka ulga, może być spłacany przez dłuższy okres, a tym samym wartość bieżąca (present value) zobowiązań podatkowych będzie mniejsza. Zaoszczędzone środki mogą być w tym czasie korzystnie zainwestowane. Oznacza to jednocześnie poprawę płynności firm, a czasem możliwość rezygnacji z kredytów krótkoterminowych. Także takie elementy, jak sposób odliczania strat od dochodu w latach następnych są znaczące $\mathrm{z}$ punktu widzenia przedsięwzięć rozwojowych. Mechanizm odliczania strat może być uznany za pewnego rodzaju automatyczny stabilizator koniunktury. $Z$ ważniejszych mechanizmów proinwestycyjnych warto jeszcze wspomnieć o preferencyjnym opodatkowaniu leasingu operacyjnego.

$\mathrm{Na}$ wielkość inwestycji przedsiębiorstwa mogą mieć wpływ także inne rozwiązania w obrębie podatku dochodowego. Dla płynności i wypłacalności podmiotu gospodarczego istotne są również warunki rozłożenia płatności podatkowych, czyli terminy płacenia zaliczek.

Do pewnego stopnia mogą także pomóc przedsiębiorstwu ulgi w spłacie zobowiązań podatkowych. Są to preferencje podatkowe przyznawane w drodze indywidualnej decyzji przez organ podatkowy ${ }^{6}$. Ulgi te mają tzw. uznaniowy charakter, co oznacza, że jeżeli organ podatkowy w konkretnej sprawie uzna,

\section{Tabela 2}

Wpływ podatku dochodowego na wybrane elementy kształtujące wielkość i opłacalność inwestycji

\begin{tabular}{|l|l|}
\hline Wpływ na: & \multicolumn{1}{|c|}{ Elementy CIT i PIT } \\
\hline $\begin{array}{l}\text { Rentowność inwestycji, ocenę } \\
\text { opłacalności inwestycji }\end{array}$ & $\begin{array}{l}\text { Stawki podatkowe, konstrukcja podstawy opodatkowania, } \\
\text { specjalne rozwiazania w zakresie amortyzacji, odliczanie } \\
\text { strat z poprzednich okresów, specjalne rozwiazania w za- } \\
\text { kresie opodatkowania leasingu }\end{array}$ \\
\hline $\begin{array}{l}\text { Koszt kapitału w poszczegól- } \\
\text { nych źródłach finansowania, } \\
\text { strukturę kapitału }\end{array}$ & $\begin{array}{l}\text { Opodatkowanie dochodów z kapitałów pieniężnych i praw } \\
\text { majatkowych, podwójne opodatkowanie dochodów }\end{array}$ \\
\hline $\begin{array}{l}\text { Poziom wyprowadzanych } \\
\text { środków z inwestycji krajowych } \\
\text { i zagranicznych kształtujący } \\
\text { poziom reinwestycji }\end{array}$ & $\begin{array}{l}\text { Stawki opodatkowania różnych form transferu dochodów } \\
\text { (dywidendy, odsetki, opłaty licencyjne), regulacje w zakre- } \\
\text { sie niedostatecznej kapitalizacji, rozwiazzania w umowach } \\
\text { dwustronnych o unikaniu podwójnego opodatkowania }\end{array}$ \\
\hline
\end{tabular}

Źródło: Opracowanie własne na podstawie ustaw o PIT i CIT. Wymieniono tylko wybrane elementy.

\footnotetext{
${ }^{6}$ Na podstawie przepisów rozdziału 7a ordynacji podatkowej.
} 
iż wystąpiła przesłanka przemawiająca za przyznaniem wnioskowanej ulgi, to może, ale nie ma obowiązku przyznania wnioskowanej ulgi.

Przez ważny interes podatnika rozumiane są różne sytuacje, które mają wpływ na brak możliwości uregulowania przedmiotowego zobowiązania w terminie płatności, ale przede wszystkim są to przypadki losowe, których podatnik nie był w stanie przewidzieć, np. choroba, pożar, a także sytuacje konieczności utrzymania miejsc pracy na danym terenie itp. .

Jednak ulgi w spłacie zobowiązań podatkowych, mając charakter uznaniowy, nie mogą być świadomie wykorzystane przez podatnika $\mathrm{w}$ procesie planowania działalności inwestycyjnej.

Wydaje się, że zakres oferowanych zachęt podatkowych w podatkach dochodowych w Polsce nie jest zbyt duży. Ewentualne zwiększenie podatkowych zachęt jest limitowane ograniczeniami w ramach pomocy de minimis ${ }^{8}$, ponadto w przypadku przeładowania systemu nadmierną ilością preferencji nie można wykluczyć pojawienia się nadużyć podatkowych w wykorzystaniu takich preferencji i związanego z nimi obniżenia dochodów budżetowych. Zakres potencjalnych ulg podatkowych jest więc limitowany między innymi przez poziom deficytu budżetowego, przepisy wspólnotowe, a także przez niejednoznaczną ocenę skuteczności podobnych rozwiązań podatkowych stosowanych w wielu krajach.

Problem preferencji podatkowych dla przedsiębiorstw wynika $\mathrm{z}$ faktu niedostatku odpowiednich i tanich źródeł finansowania dla celów rozwojowych ${ }^{9}$. Jedną z pojawiających się tutaj barier jest koszt kapitału.

Ze względu na koszt kapitału przedsiębiorstwa (spółki akcyjnej) należy więc wspomnieć o opodatkowaniu dochodów z akcji i obligacji. System podatkowy generalnie raczej nie wprowadza różnicowania zachęt do oszczędzania i zachęt do inwestowania. Są one opodatkowane w podatku PIT w ramach kategorii dochodów z kapitałów pieniężnych i praw majątkowych według tej samej stawki. Również w CIT tego rodzaju dochody są opodatkowane jednolicie. Innymi słowy lokata w banku i oprocentowanie obligacji opodatkowane są według tej samej stawki jak dochody z udziałów w zyskach i dochody ze sprzedaży akcji. Jednak nie można stwierdzić, że system podatkowy jest w analizowanym obszarze

\footnotetext{
${ }^{7}$ Ulgą w spłacie zobowiązań podatkowych jest między innymi odroczenie terminu płatności podatku, zaległości podatkowej wraz z odsetkami za zwłokę, może wystapić także rozłożenie na raty zapłaty podatku, a nawet umorzenie w całości lub w części zaległości podatkowej, odsetek za zwłokę oraz opłaty prolongacyjnej.

${ }^{8}$ Po wejściu Polski do Unii Europejskiej podmioty prowadzące działalność gospodarczą ubiegając się o udzielenie pomocy publicznej muszą również spełniać wymogi określone w przepisach wspólnotowych (Rozporządzenie Rady WE Nr 994/98 z dnia 07.05.1998 r.).

9 Jest to szczególnie dolegliwe dla małych podmiotów.
} 
neutralny. Wspiera i ukierunkowuje określone działania spółek, dyskryminuje natomiast inne.

Zasadniczo gromadzenie nowego kapitału własnego czy obcego w Polsce nie jest objęte restrykcjami w podatku dochodowym od osób prawnych. Podatkowe instrumenty regulujące proces gromadzenia kapitału własnego, rozpatrywane w izolacji, nie wskazująjednoznacznie, które ze źródeł finansowania (własne czy obce) jest korzystne fiskalnie. Jednakże podatkowe aspekty zaciagania długu wskazują na wyraźne preferencje tej formy w porównaniu z konsekwencjami emisji akcji. Powodują tę sytuację zarówno podatek dochodowy od osób prawnych, jak i podatek dochodowy od osób fizycznych, który jest konsekwencją poboru środków dla spółki kapitałowej spoza kręgu osób prawnych. Osoba fizyczna stająca się nowym akcjonariuszem spodziewa się, że zainwestowany kapitał przyniesie określony dochód. Dochód ten jest opodatkowany bez względu na formę, w jakiej się pojawia (dywidendy i zyski kapitałowe). To samo dotyczy dochodów z papierów dłużnych przedsiębiorstw, jednakże w połączeniu z podatkiem dochodowym od osób prawnych dochody udziałowe wspólników (akcjonariuszy) podlegają zwiększonemu ciężarowi podatkowemu w porównaniu $\mathrm{z}$ dochodami $\mathrm{z}$ instrumentów dłużnych ${ }^{10}$. Generalnie, regulacje podatkowe w obszarze podatków dochodowych faworyzują instrumenty dłużne (zamiast nowej emisji akcji).

Odsetki od zadłużenia są kosztem uzyskania przychodów (podobnie jak $w$ innych krajach rozwiniętych). Istnieją jednakże ograniczenia naliczania odsetek w koszty uzyskania przychodów. Jedno z nich występuje przy niedostatecznej kapitalizacji. Ograniczenie to jest wyrazem przeciwdziałania państw nielegalnemu transferowi dochodów w sposób nieopodatkowany za granicę ${ }^{11}$.

\footnotetext{
${ }^{10}$ System podatku dochodowego (relacja CIT i PIT w zakresie podwójnego opodatkowania) w Polsce zawiera elementy podatku klasycznego i częściowej integracji mającej miejsce na poziomie akcjonariusza. Charakteryzuje się on specjalną stawką opodatkowania dywidend. Występuje podwójne opodatkowanie dochodów, ale dywidendy nie są opodatkowane ściśle według modelu klasycznego. Stawka podatku od dywidend dla osób fizycznych jest niezależna od przedziału podatkowego, w którym mieszczą się ich dochody z pozostałych źródeł. Dywidendy nie są łączone $\mathrm{z}$ innymi dochodami. Można to określić jako formę integracji częściowej na poziomie podatku dochodowego od osób fizycznych. Występujący w Polsce system opodatkowania dywidend jest swego rodzaju półśrodkiem (nie jest powszechnie stosowany w innych krajach).

${ }^{11} \mathrm{~W}$ niektórych sytuacjach oprocentowanie długu nie jest kosztem uzyskania przychodu w podatku dochodowym od osób prawnych. Dzieje się tak na przykład w przypadku odsetek od pożyczek i kredytów zwiększających koszty inwestycji w okresie realizacji tych inwestycji. Koszty te następnie kształtują wartość środka trwałego będącego rezultatem inwestycji niezależnie od sposobu jej przeprowadzenia. Odsetki nie są kosztem do momentu, do którego środek trwały nie zostanie przyjęty do użytkowania. Wynika to z zasady współmierności kosztów i przychodów.
} 
Kiedy uwzględni się wpływ obu podatków dochodowych, wtedy widać, że czynnikiem podstawowym, zwiększającym opłacalność wykorzystania instrumentów dłużnych (kredytów i obligacji), jest podwójne opodatkowanie. Jego eliminacja oznaczałaby potanienie własnych źródeł finansowania.

Reasumując, zagadnienie kształtowania podstawy opodatkowania ma duże znaczenie dla wyboru optymalnej struktury kapitału przedsiębiorstwa i sposobu podziału zysku firmy. Jednak występowanie dysproporcji obciążeń pomiędzy własnymi a obcymi źródłami finansowania może być trudne do przezwyciężenia ${ }^{12}$.

Mechanizm podwójnego opodatkowania dochodów w przypadku wypłat dywidend powoduje, że przyrost kapitałów własnych jest do pewnego stopnia dyskryminowany przez podwójne opodatkowanie. Mechanizm podatkowego kształtowania opłacalności wykorzystania kapitału własnego współdecyduje więc także o opłacalności podatkowej funkcjonowania określonych form przedsiębiorstw. Integracja podatku dochodowego (tzn. eliminacja podwójnego opodatkowania) wywołuje rozmaite pytania i problemy. Należy do nich między innymi zagadnienie jej wpływu na politykę finansową firm, a także na dystrybucję dochodów i akumulację kapitału w przedsiębiorstwie.

W rozważanym obszarze powstały różne koncepcje teoretyczne zmierzające do reformy podstawy opodatkowania w podatku dochodowym od osób prawnych. Celem ich opracowania jest nie tylko ograniczenie podwójnego opodatkowania, ale także wyeliminowanie braku neutralności podatkowej z punktu widzenia przedsiębiorstwa. Do koncepcji takich należą koncepcja ACE (allowance for corporate equity), w której zakłada się, że w podatku dochodowym można uwzględnić koszty finansowania własnego analogicznie do kosztów odsetkowych. Można w ten sposób zrównać podatkowe konsekwencje finansowania własnego i finansowania obcego oraz uniknąc ewentualnych zakłóceń związanych $\mathrm{z}$ wyborem form finansowania.

Następną propozycję stanowi CBIT (comprehensive business income tax), który zrównuje obie formy finansowania w inny sposób, tzn. poprzez uniemożliwienie zaliczenia odsetek do kosztów uzyskania przychodów w podatku dochodowym od osób prawnych [Bond 2000, s. 161-180].

W obu tych projektach nie dokonuje się działan dostosowawczych na poziomie podatku dochodowego od osób fizycznych.

${ }^{12} \mathrm{~W}$ praktyce, aby uzyskać podstawową neutralność źródeł finansowania w zakresie kapitału własnego i długu na poziomie CIT, potrzebny byłby zabieg polegający na umożliwieniu odliczania od zysku przed opodatkowaniem kosztów kapitału własnego dla celów podatkowych bądź na zaliczeniu ich do kosztów uzyskania przychodów w podatku dochodowym od osób prawnych. Inne rozwiązanie to brak jakichkolwiek możliwości uznawania wydatków odsetkowych za koszty uzyskania przychodów w CIT. Jednak odsetki powszechnie uważa się za koszty uzyskania przychodów dla celów podatkowych i są one tym kosztem z ekonomicznego punktu widzenia. 
Koncepcja ACE powoduje, że źródła finansowania działalności osób prawnych tanieją, podczas gdy koncepcja CBIT powoduje, że źródła finansowania ich działalności drożeją. Jednak w rzeczywistości większość państw rozwiniętych wykorzystuje systemy integracji częściowej (a czasem pełnej) podatku dochodowego. Bardziej racjonalne od metod częściowej, a nawet pełnej integracji wydają się koncepcje ACE i CBIT, które próbują dokonać neutralizacji podatkowej finansowania własnego i finansowania obcego w podmiotach gospodarczych. Systemy ACE i CBIT są proste, jednakże ze względu na fiskalne interesy państwa potraktowanie kosztu kapitału własnego jako kosztu uzyskania przychodów (ACE) wydaje się rozwiązaniem mniej korzystnym od różnych form integracji. Ponadto przy systemie ACE nie można różnicować korzyści osiaganych przez inwestorów krajowych i zagranicznych z tytułu osiaganych dywidend. Różne modelowe próby aplikacji tych systemów pokazują, że byłyby one korzystne dla stosujących je krajów, ale wydaje się, iż w pierwszej kolejności trzeba byłoby do tego przekonać polityków gospodarczych [Devereux, de Moiij 2011, s. 93-120].

Problem reinwestowania zysków w Polsce przez zagraniczne i krajowe podmioty obejmuje elementy podatkowe kształtujące decyzje przedsiębiorstw, znajdujące się w regulacjach podatkowych o charakterze umów międzypaństwowych oraz rozwiązania zawarte w systemach podatkowych innych krajów. Decyzje przedsiębiorstw uwzględniają więc regulacje podatkowe innych krajów. Krajowe władze podatkowe nie mogą warunków transferu kapitału kształtować samodzielnie. Teoretyczne koncepcje neutralności podatkowej eksportu kapitału (CEN) i neutralności podatkowej importu kapitału (CIN) mają w warunkach funkcjonowania systemów podatkowych wielu państw bardzo niewielkie szanse na wdrożenie ze względu na przeciwstawne interesy podatkowe krajów goszczących inwestorów zagranicznych i krajów ich siedziby. Zagadnienie to nie będzie tutaj obszerniej omawiane.

\section{Podsumowanie}

$\mathrm{Z}$ punktu widzenia teoretycznego wszelkie preferencje w ramach podatków dochodowych nakierowane na wzrost inwestycji oznaczają naruszanie zasady neutralności opodatkowania. Dotyczy to zarówno inwestycyjnych preferencji podatkowych, jak i wyrównania podatkowych warunków finansowania ich działalności, w tym działalności inwestycyjnej. Może to powodować zakłócanie funkcjonowania mechanizmu rynkowego. W teorii formułowane są różnorodne pomysły dotyczące rozwiązań podatkowych, które mogą ograniczyć poziom zakłócania tej neutralności. Część z nich może być wdrożona w życie. Wydaje się 
jednak, że spełnienie tej zasady to wciąż bardziej życzenie niż rzeczywistość gospodarcza. Trudno zresztą wymagać od państwa zupełnej nieingerencji w sprawy podmiotów gospodarczych.

W praktyce polityka państwa, w tym także polityka podatkowa, może wywierać duży wpływ na działalność rozwojową przedsiębiorstw. Czynnik ten nie może być ignorowany przez podmioty gospodarcze i nieraz w znaczący sposób modyfikuje ich działania w sferze realnej i finansowej. Celem tej polityki jest między innymi kształtowanie decyzji podmiotów gospodarczych. Takie działania podważają dość często wysuwany w teorii podatków postulat dotyczący neutralności polityki fiskalnej.

Jednak obecnie w podatkach dochodowych znajduje się niewiele regulacji nakierowanych bezpośrednio lub pośrednio na przyrost inwestycji w podmiotach gospodarczych i chyba nie należy spodziewać się żadnych dużych zmian w najbliższej przyszłości. Obniżki stawek podatków CIT i PIT (stawka liniowa) od 2004 roku wydają się być wciąż zasadniczą zmianą w ostatnich kilkunastu latach. Oznacza to, że w tym obszarze istnieje tendencja do zwiększania neutralności opodatkowania (prawdopodobnie bez takich intencji).

Rozważając zagadnienie od strony praktycznej można powiedzieć, że preferencje podatkowe mogłyby wpłynąc na opłacalność inwestycji w przedsiębiorstwie. Jednak rozszerzanie systemu preferencji zawsze powoduje obniżkę dochodów budżetowych, powstawanie nieprzewidywanych skutków ubocznych, wreszcie zakłóca kryteria rynkowe opłacalności inwestycji, czyli narusza zasadę neutralności. Utrudnieniem dla wprowadzenia rozszerzonego systemu preferencji są także akceptowane przez Polskę ograniczenia międzynarodowe.

\section{Literatura}

BOND S.R., Levelling Up or Levelling Down? Some Reflections on ACE and CBIT Proposals, and the Future of the Corporate Tax Base, w: S. CNOSSEN (red.), Taxing Capital Income in the European Union, Oxford University Press, Oxford 2000, s. 161-180.

CHUA D., KING J.R., The Mechanics of Integration, w: Tax Policy Handbook (red. Parawashati Shome), Washington, International Monetary Fund Staff Papers, 1995, s. 151-154 .

DAVIS E.W, POINTON J., Finanse i firma, PWE, Warszawa 1997.

DEVEREUX M., de MOIIJ R., An Applied Analysis of ACE and CBIT Reforms in the EU?, International Tax and Public Finance 2011, 18 (1), s. 93-120.

GRĄDALSKI F., System podatkowy $w$ świetle teorii optymalnego opodatkowania, SGH 2006.

HARBERGER A.C., Tax Neutrality in Investment Incentives, w: H.J. Aaron i M. J. Boskin, The Economics of Taxation, Brookings, Washington D.C. 1980, s. 299-313.

MINTZ J., The Corporation Tax, Fiscal Policy 1995, 16 (4), s. 1-20. 
OECD, Tax Policy Reform and Economic Growth, Paris: OECD, 2010.

Ustawa z dnia 26 lipca 1991 roku o podatku dochodowym od osób fizycznych (Dz.U. z 1991 r. $\mathrm{Nr} 80$, poz. 350 ze zm.).

Ustawa z dnia 15 lutego 1992 roku o podatku dochodowym od osób prawnych (Dz.U. z 1992 r. $\mathrm{Nr} 21$, poz. 86 ze zm.).

\title{
Investment tax preferences and tax principles
}

\begin{abstract}
There are numerous factors that can influence the level of investment in fixed assets of enterprises. The tax incentives can also influence the level of investment in fixed capital. They have their advantages and disadvantages. Some of the corporate tax incentives are described in this paper. Theoretical analysis of neutrality is an essential tool applied to this research. Lack of neutrality proves that tax system awards some company activities and, therefore, it states the level of their income.
\end{abstract}

